\title{
Interaction between the Family Health Units and the Academia da Cidade Program in Recife, Northeastern Brazil
}

\author{
Articulação entre as Unidades de Saúde da Família e o Programa \\ Academia da Cidade no Recife
}

\section{Raquel Bezerra Pajeú1, Juliana Ribeiro Falcão Cavalcanti , Vanessa Luiza Gomes de Moura', Cícero Adriano Melo Figueirê- do', Vandepaula Moraes Campos de Melo ${ }^{1,2}$, Emmanuelly Correia de Lemos}

\begin{abstract}
The objective of this study was to analyze the relationship between the professionals of the Family Health Units (FHU) from Recife and the Academia da Cidade Program (ACP). A descriptive cross-sectional study with a quantitative approach was performed. The study population consisted of 203 professionals from 48 FHUs located two kilometers away from the ACP centers. Data were collected through the application of a self-administered questionnaire from prescheduled visits to the FHU. The variables were related to socio-demographic aspects, professional category, knowledge about the ACP and interaction between the two services. Data tabulation was conducted in the EpiData Entry software, version 3.1. In addition, the SPSS software, version 10.0, was used for the quantitative analysis and results were shown in absolute and relative frequencies. Most respondents were female (89.2\%), aged between 30 and 39 years old (37.4\%). The majority (95.0\%) claimed to know the ACP and the FHUs in their health district (76.5\%), although $81.4 \%$ had not performed an intervention in the Program centers. Even though 51.3\% informed that the Program conducts interventions in their unit, almost half $(50.9 \%)$ reported never inviting ACP professionals to staff meetings. The referral and counter-referral of users showed a low frequency both from the FHU to the ACP and from the ACP to the FHU. It can be concluded that, although there is interaction between professionals from the FHU and the ACP, this appears to be incipient, indicating that they have not yet established an integrated and continuous relationship with the ACP.
\end{abstract}

\section{Keywords}

Family Health; Primary Health Care; Intersectoral Action; Motor Activity.

\section{Resumo}

O objetivo desse estudo foi analisar a articulação entre os profissionais das Unidades de Saúde da Familia (FHU) do Recife e o Programa Academia da Cidade (PAC). Estudo transversal, descritivo, de abordagem quantitativa. A população foi composta por 203 profissionais de 48 FHU que estavam localizadas a dois quilômetros dos polos do PAC. A coleta de dados ocorreu por meio da aplicação de um questionário autoaplicado, a partir de visita pré-agendada nas unidades. As variáveis analisadas foram relacionadas ao perfil sociodemográfico, formação profissional, conbecimento sobre o PAC e articulação entre os dois serviços. A tabulação dos dados foi efetuada no programa EpiDataEntry v. 3.1. Para análise dos dados quantitativos foi utilizado software SPSS versão 10.0 e os resultados foram apresentados em frequências relativas e absoluta. A maior parte dos entrevistados foi do sexo feminino (89,2\%), com idade entre 30 e 39 anos (37,4\%). A maioria (95,0\%) afirmou conhecer o PAC e os polos do seu distrito sanitário (76,5\%), porém $81,4 \%$ nunca fez intervenção nos polos. Embora $51,3 \%$ tenha informado que o PAC realiza intervenção na sua unidade, quase metade (50,9\%) afirmou nunca convidar os profissionais do PAC para as reuniões de equipe. A referência e contrarreferência de usuários apresentou baixa frequência tanto das FHU para o PAC quanto o inverso. Conclui-se que embora exista articulação entre os profissionais das FHU e o PAC, ela parece ser incipiente, indicando que eles ainda não estabeleceram com o PAC uma relação integrada e contínua.

Palavras-chave

Saúde da Familia; Atenção Primária à Saúde; Ação intersetorial; Atividade física.

\section{Introduction}

The number of physical activity promotion programs

1 School of Physical Education, Federal University of Pernambuco, Postgraduate Program - Specialization.

2 Postgraduate Associated Program in Physical Education, Federal University of Pernambuco/Federal University of Paraíba. developed in the context of the Sistema Unico de Saúde (UHS - Unified Health System) has increased in Brazil in general ${ }^{1}$, in accordance with the SUS principles and population requirements ${ }^{2}$. The following are examples of such programs, all aimed at encouraging 
the practice of physical activities for the population ${ }^{3}$ : Academia da Cidade Program (ACP), created in 2002 by the Recife City Hall; the Academia das Cidades Program (ACSP), created in 2007 by the Department of Cities of the state of Pernambuco; and the Academia da Saúde Program (ASP), created in 2011 by the Ministry of Health from successful experiences in several cities such as Recife.

The ACP is a health promotion strategy mainly aimed at contributing to the promotion of collective health. This is achieved through the encouragement of and guidance on physical activity practice, leisure and healthy eating, including systematic actions performed in public spaces (squares, parks and waterfront) known as centers, receiving users as free demand or referred by the network ${ }^{1}$.

The actions performed by this Program are within the sphere of health promotion through physical activity practice, physical fitness assessment and health education. They are developed by Physical Education professionals who work for 30 hours per week. Aiming to increase the scope of this program, ACP professionals spend half of these hours at the centers, while the other half includes the development of interventions for different population groups, such as pregnant women, elderly individuals, hypertensive individuals, diabetics and adolescents, in addition to other social and health services, such as associations of residents, churches, Centros de Atenção Psicossocial (PCC - Psychosocial Care Centers) and Unidades de Saúde da Familia (FHU - Family Health Units) ${ }^{1}$.

Included in Primary Health Care (PHC) in the city of Recife since its implementation in 2002, the ACP is a center of the Rede de Atenção à Saúde (HCN - Health Care Network), which corresponds to the interaction between health services and systems and the relationship among its participants. This Health Care Network was created with the purpose of helping cities to organize their services and of guaranteeing users' universal and comprehensive access to the UHS, enabling them to move across this network, using services on all its levels, with PHC as the ordering and regulating point of this flux ${ }^{4}$.

The ACP increases PHC services in a way that complements and maximizes individual and group care actions. Therefore, it should be associated to this network in an interactive and systematic way, aiming to provide health care to users and to establish connections and a mutual support network, apart from being a gateway to the UHS. According to Lemos ${ }^{5}$, the interaction between the ACP and the FHU is key both to raise the offer of services to care for specific conditions (diseases) and to increase adherence to the practice of physical activities and other eating habits as part of the routine of life of individuals.

Regarding research projects that had the ACP or other similar programs in different Brazilian regions as the object of study, the aim was different, such as users' and professionals' satisfaction with the Program ${ }^{6-10}$, while other studies focused on the relationship among the several Health Care Network programs in Brazil on all their levels ${ }^{11,12}$. In this sense, considering the fact that the fragmentation of the health system in this country is still a great obstacle, it can be assumed that there is an interaction between the ACP and FHUs, although it can be superficial, emphasizing the relevance of studies on such interaction in this case. Moreover, the results found here can also contribute to other similar programs, such as the ASP, with an estimated construction of 4,000 centers all over Brazil by 2018 (including 275 centers in Pernambuco ${ }^{13}$.

In view of what has been described, the present study aimed to analyzed the interaction between FHU health professionals in Recife and the ACP, according to practices developed in the daily routine of FHU teams for this program. 


\section{Methods}

A cross-sectional descriptive study with a quantitative approach was conducted, originated from a research project entitled "Inclusion of the Academia da Cidade Program in Primary Health Care in the City of Recife: Perception of Academia da Cidade Program and Primary Health Care Professionals.”

The places of study were the FHUs distributed across eight health districts in the city of Recife, located within a radius of two kilometers of distance from the ASP centers. This is because the FHUs that were closest to these centers had better conditions to develop continuous activities integrated with this program. The source used to verify the addresses of the places of study was the Cadastro Nacional de Estabelecimento de Saúde (BRHE - Brazilian Register of Health Establishments). Google Maps was used to calculate the walking distance between these centers and the units. The sample was comprised of at least one Professional of each FHU category. Professionals who, at the moment of this study, were on vacation or those on sick, maternity, bonus or study leaves were excluded.

A total of 68 FHUs were expected to be visited, including 408 professionals. However, it was not possible to collect data in 20 such units, due to obstacles caused by the logistics of the visits in units located in areas of difficult access, or due to repeated visits to certain units without a successful collection. Among the 48 FHUs where data collection was performed, 71 professionals were lost and 14 refused to participate in this study, of which $75 \%$ were females and $29.4 \%$ were physicians. The two main reasons for not responding to the questionnaire were as follows: to be busy/to have no time (33.7\%); and not to be present in the unit when researchers were there (28.7\%). Thus, the final sample totaled 203 professionals.

The data collection instrument was a self-administered questionnaire for Family Health Unit professionals. This questionnaire was designed with objective questions, based on more recent studies on this theme. It was organized into the following four sections: (1) socio-demographic aspects and professional category, (2) knowledge about physical activity, (3) knowledge about the ACP, and (4) interaction with the ACP. The variables analyzed in this study were associated with sections 1 and 4: socio-demographic aspects and interaction with the ACP respectively, as shown in Figure 1.

Data collection was conducted by postgraduate students from the University of Pernambuco (students participating in this study), who were adequately trained (a previous training program was performed with the entire team) to apply this questionnaire. Data were collected through interviews that had been pre-scheduled in the FHUs of the health units and conducted from July to August 2015.

The procedure for data tabulation was performed in the EpiDataEntry software (version 3.1). Quantitative data were analyzed with the SPSS software, version 10.0, with the results shown as relative and absolute frequencies.

The research project to which this study is connected was approved by the Human Research Ethics Committee of the University of Pernambuco - under CAAE: 45622215.8 .0000 .5192 . Individuals participated voluntarily by signing an Informed Consent Form.

\section{Results}

A total of $203 \mathrm{FHU}$ professionals participated in this study, the majority of which were females, aged between 30 and 39 years. Regarding professional category, most participants were community health agents (30.6\%), followed by nurses (18.7\%), nursing technicians $(15.8 \%)$, physicians $(13.8 \%)$, dentists $(12.8 \%)$, oral health tech- 
nicians (4.4\%), and oral health assistants (3.9\%). In terms of qualification, 92.4\% reported having had disciplines in Collective Health; and 87.5\%, in Health Promotion (Table 1).

\begin{tabular}{|c|c|}
\hline Population & Section and variables analyzed \\
\hline \multirow{3}{*}{$\begin{array}{l}\text { Family Health Units (FHU) } \\
\text { professionals }\end{array}$} & $\begin{array}{l}\text { Socio-demographic aspects } \\
\text { - Sex; } \\
\text { - Age; } \\
\text { - Level of education; } \\
\text { - Professional category; } \\
\text { - Length of time working in the network; } \\
\text { - Qualification in the service to work with other programs; } \\
\text { - Number of locations where one worked. }\end{array}$ \\
\hline & $\begin{array}{l}\text { Knowledge about the Academia da Cidade Program (ACP) } \\
\text { - Knows the program; } \\
\text { - Knows the centers in the same district of the unit; }\end{array}$ \\
\hline & $\begin{array}{l}\text { Interaction with the ACP } \\
\text { - The FHU performs or has performed an intervention with the Program; } \\
\text { - Perception of change in users' health condition after intervention with } \\
\text { the Program; } \\
\text { - Perception of change in users' habits after intervention with the } \\
\text { Program; } \\
\text { - Frequency that Program professionals are invited for meetings; } \\
\text { - Assessment of the intervention performed by a Program professional in } \\
\text { the FHU; } \\
\text { - Intervention in a ACP center; } \\
\text { - Referral and counter-referral. }\end{array}$ \\
\hline
\end{tabular}

FIGURE 1 - Distribution of the variables analyzed.

The majority of interviewees (95.0\%) affirmed that they knew the ACP and $76.5 \%$ supposedly knew where the centers in their district were located. However, the majority $(81.4 \%)$ reported never having performed an intervention in such centers.

This figure changes in terms of interventions performed by ACP professionals in the FHUs, as slightly more than half of participants (51.3\%) affirmed that Program professionals performed or had already performed an action in their unit for at least three months of duration. Among professionals who reported having experience with this intervention, $86.7 \%$ perceived changes in both health condition and habits of users participating in such actions (Table 2).

Participants were questioned about the frequency with which FHU professionals invited ACP professionals to discuss cases in their unit and to develop the Projeto Terapêticico Singular (STP - Singular Therapeutic Project), thus forming the multi-disciplinary team. The majority (50.9\%) reported having never made such an invitation. However, of all those that answered "always" (12.1\%) or "almost always" (6.1\%) inviting program professionals, most considered the participation of such professionals in meetings to be very important (Table 2).

Regarding the referral and counter-referral between units and ACP centers, professionals were questioned whether they had already referred users to centers, both formally, using a network referral form, an informally, without such form. Additionally, they were asked whether they had already received users who had been referred by a certain Program center, both formally and informally (Table 3). The results show that the majority of interviewees had never formally referred unit users to the ACP (87.1\%), although informal referrals had been made. The number of FHU professionals who reported having never received users formally referred to their unit by Program centers was even higher (95.9\%). Even the percentage for informal referrals was high. 
TABLE 1 - Socio-demographic profile and performance of primary health care professionals in Recife-PE, Brazil, 2015.

\begin{tabular}{|c|c|c|}
\hline Variable & N & $\%$ \\
\hline \multicolumn{3}{|l|}{ Sex } \\
\hline Female & 181 & 89.2 \\
\hline Male & 22 & 10.8 \\
\hline \multicolumn{3}{|l|}{ Age group* } \\
\hline 20 to 29 & 12 & 6.1 \\
\hline 30 to 39 & 74 & 37.4 \\
\hline 40 to 49 & 59 & 29.8 \\
\hline 50 to 59 & 40 & 20.2 \\
\hline 60 or more & 13 & 6.6 \\
\hline \multicolumn{3}{|l|}{ Level of education } \\
\hline Technical & 54 & 26.6 \\
\hline Secondary education & 29 & 14.3 \\
\hline Higher education - undergraduate & 28 & 13.8 \\
\hline Higher education - specialization & 81 & 39.9 \\
\hline Master's degree & 9 & 4.4 \\
\hline Doctoral degree & 2 & 1.0 \\
\hline \multicolumn{3}{|l|}{ Professional category } \\
\hline Community health agent & 62 & 30.6 \\
\hline Physician & 28 & 13.8 \\
\hline Nurse & 38 & 18.7 \\
\hline Nursing technician & 32 & 15.8 \\
\hline Dentist & 26 & 12.8 \\
\hline Oral health technician & 9 & 4.4 \\
\hline Oral health assistant & 8 & 3.9 \\
\hline \multicolumn{3}{|l|}{ Length of time working in $\mathrm{PHC}$ (in years)* } \\
\hline 1 to 5 & 36 & 18.1 \\
\hline 6 to 10 & 50 & 25.1 \\
\hline 11 to 15 & 63 & 31.7 \\
\hline 16 to 20 & 30 & 14.8 \\
\hline 21 to 25 & 14 & 7.0 \\
\hline 26 to 30 & 6 & 3.0 \\
\hline \multicolumn{3}{|c|}{ Qualification in the service to work with other health care network programs* } \\
\hline Yes & 158 & 80.6 \\
\hline No & 38 & 19.4 \\
\hline \multicolumn{3}{|c|}{ How many health districts one has worked in* } \\
\hline One & 147 & 75.4 \\
\hline Two & 36 & 18.5 \\
\hline Three & 8 & 4.1 \\
\hline Four or more & 4 & 2.1 \\
\hline \multicolumn{3}{|l|}{ How many FHU one has worked for* } \\
\hline One & 102 & 50.5 \\
\hline Two & 53 & 26.2 \\
\hline Three & 26 & 12.9 \\
\hline Four & 9 & 4.5 \\
\hline Five or more & 12 & 5.9 \\
\hline
\end{tabular}

* Variable with missing values (lack of response from some participants). 
TABLE 2 - Characteristics of the performance of the Academia da Cidade Program in the Family Health Units (FHU), Recife-PE, Brazil, 2015.

\begin{tabular}{lcc}
\hline Variable & N & $\%$ \\
\hline There is Program action in the $\mathrm{FHU}^{*}$ & 14 & 7.5 \\
\hline Does not know & 96 & 51.3 \\
\hline Yes & 77 & 41.2 .9 \\
\hline No & & \\
\hline Perceived changes in users' health conditions** & 78 & 86.7 \\
\hline Yes & 12 & 13.3 \\
\hline No & & \\
\hline Perceived changes in users'life habits & 78 & 13.1 \\
\hline Yes & 12 & 50.9 \\
\hline No & & 30.9 \\
\hline Frequency that Program professionals are invited for meetings* & 84 & 6.1 \\
\hline Never & 51 & 12.1 \\
\hline Sometimes & 10 & 34.6 \\
\hline Almost always & 20 & 65.4 \\
\hline Always & 9 & \\
\hline Assesses the participation of Program professionals in meetings when invited & \\
\hline Important & 17 & \\
\hline Very important & & \\
\hline
\end{tabular}

* Variable with missing values (lack of response from some participants); ** Variable with missing values (lack of response from some participants, as it was not applicable, because it depended on previous question).

TABLE 3 - Referral and counter-referral between Family Health Units (FHU) and Academia da Cidade Program (ACP), Recife-PE, Brazil, 2015.

\begin{tabular}{lcc}
\hline Variable & $N$ & $\%$ \\
\hline $\begin{array}{l}\text { Formally referred user from the FHU to the Program* } \\
\text { Yes }\end{array}$ & 22 & 12.9 \\
\hline No & 148 & 87.1 \\
\hline Informally referred user from the FHU to the Program* & 118 & 69.4 \\
\hline Yes & 52 & 30.6 \\
\hline No & 7 & 4.1 \\
\hline Received user formally referred from the Program to the FHU* & 95.9 \\
\hline Yes & 163 & 18.0 \\
\hline No & & 82.0 \\
\hline Received user informally referred from the Program to the FHU* & 30 & \\
\hline Yes & 137 & \\
\hline No & & \\
\hline
\end{tabular}

* Variable with missing values (lack of response from some participants).

\section{Discussion}

The present study enabled us to identify the fact that, although nearly half of participants had reported that their FHUs perform continuous actions (lasting at least three months) with users in a partnership with ACP professionals, they perform few actions with such program professionals, indicating a random interaction between these two programs. The higher number of ACP interventions in FHUs to the detriment of unit actions in Program centers can be justified by the fact that this program adopts the development of actions in partnership with the FHUs as a strategy to increase its reach in the area ${ }^{1}$. 
As the majority of professionals who reported that ACP actions are performed in their unit perceived favorable changes in users' health conditions and habits after interventions from Program professionals, such actions were found to be positive. A study conducted by Hallal et al. ${ }^{10}$, in the perspective of the assessment of the ACP, revealed that individuals participating in this Program had a better perception of their health condition than those who did not. Furthermore, it found that users had undergone changes in life habits, related to both the adoption of physical activities and improvements in eating habits. A study on physical activity level and factors associated with physical inactivity in users of a primary health unit ${ }^{14}$, performed in the city of Belo Horizonte, Southeastern Brazil, showed that this level was higher among participants who knew the ACP in this city than those who did not. Likewise, in a study performed with ACP users of the city of Petrolina, Northeastern Brazil, Brandão et al. ${ }^{8}$ indicated that scores of self-reported life and health habits increased with the number of days of participation of users in the program.

However, a low level of participation was found regarding interventions of FHU professionals in ACP centers, due to the reduced number of professionals who reported having already developed actions in a certain center.

In addition, the results show that, although these activities were or have been continuous as their minimum duration is three months, such connection still reveals some vulnerabilities. The reason is that few FHU professionals affirmed inviting ACP professionals for team planning meetings to discuss cases and construct a Singular Therapeutic Project together. A similar difficulty was reported in a study that analyzed the actions of the Núcleo de Apoio à Saúde da Familia (FHSC Family Health Support Center) of a city in the state of Pernambuco, Northeastern Brazil, performed by Physical Education (PE) professionals. In this center, even in the case of physical activities performed by the FHSC which were being developed in partnership with the FHU team, PE professionals reported difficulties in planning actions and organizing work processes with the unit's professional categories ${ }^{15}$. When analyzing the intervention of PE professionals in the FHSC of cities of Northern Paraná state, Souza and Loch ${ }^{16}$ also mentioned this problem, indicating a possible difficulty encountered by FHU health professionals when working intersectorally and revealing the need to develop the formation of bonds with Primary Health Care.

The majority of those who reported having invited the ACP professionals for unit team meetings assessed their participation at such moments as relevant, in accordance with the recommendation from the Ministry of Health for the construction of ASPs in areas covered by the referral Primary Health Care establishment, aiming to facilitate the relationship between these two health services, strengthening the network and promoting comprehensive care for users ${ }^{17}$. In a study conducted through interviews with Family Health teams from the city of Porto Velho, Northern Brazil, interviewees reported that they considered the participation of PE professionals to be important in the planning and execution of FHU actions ${ }^{18}$.

With regard to referrals and counter-referrals, the results of the present study showed that both the referrals made by the units for the ACP and those made by this program for the units are low, especially regarding formal referrals with the use of standard forms and signed by health professionals, although program centers and units are physically close to each other and belong to the same area. These results show the difficulty in dealing with the complexity of decentralizing health care by these two programs. Additionally, they also reveal the FHU teams' possible lack of recognition of the role of the ACP as a health promotion ser- 
vice which is part of the Health Care Network, or a lack of knowledge about its characteristics, objectives, work processes and actions developed. This exposes a general problem, that of network fragmentation on all its levels, which directly compromises the comprehensiveness of care provided to SUS users. The findings from this study also point to ACP professionals' difficulty in understanding both the role of the FHU in the network and its attributions with regard to Physical Education professionals inside this network and the importance of the relationship between these two programs. This difficulty has already been pointed out in a study conducted by Hallal et al. ${ }^{9}$ with ACP professionals, who mentioned the lack of interaction between these programs when referring users as one such problem.

Some studies published in different areas reveal the obstacle to the referral and counter-referral process between health services in this network. A study was performed, aiming to assess the flux of patients to a dental specialties center in Southeastern Brazil ${ }^{19}$ showed that even with the developments observed in the city assessed, there is still the difficulty in the interaction among services. Likewise, in their study on obstacles to user access to health care networks, Sousa et al. ${ }^{20}$ observed a lack of communication between professionals and primary and specialized health care services in the city of Recife.

Similar results were found in the studies conducted by Serra and Rodrigues ${ }^{21}$ and Protásio et al. ${ }^{22}$, when analyzing the flux of referrals and counter-referrals in the Family Health Strategy of the states of Rio de Janeiro and Paraíba respectively, particularly in terms of counter-referrals.

The low percentage of referrals and counter-referrals between the ACP and the FHU shows the obstacles to communication between these programs. They cannot establish a process of co-participation in action planning and co-responsibility for user care, although the FHU offers activities conducted by program professionals, showing a still fragmented view on health care, hindering the flux of users in the network, and the difficulty in performing intersectoral work.

Certain study limitations should be emphasized, such as the difficult access to and reception in some FHUs. Moreover, certain professionals were not easily available to participate in this study, although researchers adopted some strategies to facilitate data collection, such as: taking advantage of moments such as team meetings; visiting units more than once and at different times; and scheduling data collection in advance. Another limitation was the fact that the group of researchers could not go to all FHUs expected to be visited in the sample.

According to the results of the present study, we could observe an interaction between the Family Health Units and the ACP. However, with regards to FHU practices related to this program, such interaction seems to be incipient. This could mean that FHU professionals and ACP professionals have not established integrated work between themselves. Consequently, this program has not been consolidated as a health promotion instrument in the area covered by the unit, which could contribute to the increase in health care actions for users, thus enabling the implementation of the Health Care Network. This is a fact that points to the vulnerability of the interaction between these programs and reveals the difficulty in the integration of such network as a whole $e^{4}$.

The ACP and the Family Health Strategy still have a long way to go in terms of the construction/development of a support network between them. Investments in continuing education for the health care network in Recife are required, regarding the instruments found in the area and the importance of integrated work, apart from meetings that can promote the formation of professional bonds 
through the appreciation of interpersonal relationships between ACP and FHU teams. It is essential that research projects with a more complex approach be conducted, aiming to overcome the limitations previously described here and to increase knowledge about the theme approached by this study.

\section{Acknowledgements}

Authors would like to thank the FHUs for their availability to participate in the present study; the researchers/professionals who were part of the greater research project that included this study; the Recife City Hall; the ACP for always investing in our qualification; and the Federal University of Pernambuco for the partnership formed with the City Hall.

\section{Author contributions}

All authors participated in the creation of the research project or data analysis and interpretation, article writing, relevant critical review of the intellectual content, and final approval of the version to be published.

\section{References}

1. Lemos EC, Gouveia GC, Luna CF. Academia da Cidade Program: The Experience of Recife. In: Gurgel IGD, Medeiros KR, Aragão AV, Santana, RM (eds). Public Health Management: contributions to the policy. Recife: Editora UFPE; 2014. p. 140-53

2. Mendes VM, Carvalho YM. Without a beginning or an end... with the body practices and Increased Clinic. Interface-Comunicação, Saúde, Educação. 2015; 19 (54): 603-13.

3. Silva, JA. Practice of monitoring and assessment in interventions to promote physical activity in Primary Health Care in the state of Pernambuco [Master's dissertation]. Recife: Universidade de Pernambuco; 2015.

4. Mendes EV. Health care networks. CienSaude Colet. 2010; 15(5): 2297-305.

5. Lemos EC. Determinants of adherence and non-adherence to the Academia da Cidade Program [Master's dissertation]. Recife: Centro de PesquisasAggeu Magalhães/FIOCRUZ PE; 2012.

6. Lopes AS, Toledo MT, Câmara AC, MenzelHK, Santos LC. Health conditions and counseling about diet and physical activity in Primary Health Care in the city of Belo Horizonte-MG. Epidemiol. Serv. Saúde. 2014; 23(3): 305-16.

7. Padilha MA, Oliveira CM, Figueiró AC. Study on the availability of the Rio de Janeiro Academia de Saúde Program: challenges for health promotion. Saúde debate. 2015; 39(105): 375-86.

8. Brandão JS, Andrade ES, de Souza DE, Gama TD, Magnani, KL, Freitas RP. Self-reported health and quality of life in individuals practicing walking in the Academia das Cidades Program, Petrolina-PE, Brazil. Rev Bras Promoç Saúde.2012; 25(2): 167-75.

9. Hallal PC, Carvalho YM, Tassitano RM, Tenório MM, Warschauer M, Reis RS, et al. Qualiquantitative assessment of the Academia da Cidade Program, Recife-PE: the concept of professors. RevBrasAtivFis e Saúde. 2009; 14(1): 9-14.

10. HallalPC, Tenório MM, Tassitano RM, Reis RS, Carvalho YM, Cruz DA, et al. Evaluation of the Academia da Cidade Program to promote physical activity in Recife-PE, Brazil: perceptions of users and non-users. Cad. SaúdePública. 2010; 26(1): 70-8.

11. Quinderé PD, Jorge MB, Nogueira ML, Costa LA, Vasconcelos MF.

12. Accessibility and resolvability of mental health care: the experience of matrix support. Cien Saude Colet. 2013; 18(7): 2157-66.

13. Costa JP, Jorge MB, Vasconcelos MF, Paula ML, Bezerra IC. Resolvability of care in primary health care: multi-professional interaction and service network. Saúde Debate. 2014; 38(103): 733-43.

14. Brasil, MS. Strategic action plan to deal with chronic Non-Communicable Diseases (NCD) in Brazil 2011 - 2022. Brasil, 2011.

15. Ramalho JD, Lopes AS, Toledo MT, Peixoto SV. Physical activity level and factors associated with physical inactivity in users of a primary health unit in Belo HorizonteMG. Rev Min Enferm. 2014;18(2): 426-32. 
16. Guarda RB, Silva RN, Silva SM, Santana PR. Physical activity as a supporting tool for actions in Primary Health Care. RevBrasAtivFis e Saúde. 2014; 19(2): 265-70.

17. Souza SC, Loch MR. Intervention of Physical Education professionals in Family Health Support Centers in cities in Northern Paraná state. Rev. Bras. RevBrasAtivFis e Saúde. 2011; 16(1): 5-10.

18. Brasil, Health Ministry. Decree number 2681, November 7th 2013: Redefines the Academia da CidadeProgram in the sphere of the Sistema Único de Saúde (SUS - Unified Health System). Diário Oficial da República Federativa do Brasil, 2013.

19. Pedrosa OP, Leal AF. The inclusion of Physical Education professionals in the Family Health Strategy in a capital city of Northern Brazil. Movimento. 2012; 1 (2): 235-53.

20. Rodrigues LA, Vieira JDM, Leite IG. Assessment of the flux of referrals to a dental specialty center implemented in a medium-size city in Southeaastern Brazil. Cad. Saúde Colet. 2013; 21(1): 40-5.

21. Sousa FO, Medeiros KR, Gurgel Júnior GD, Albuquerque PC. From the normative to the reality of the Unified Health System: revealing barriers to the access to the health care network. CienSaudeColet. 2014; 19(4): 1283-93.

22. Serra CG, Rodrigues PD. Evaluation of reference and counter-reference in the Family Health Program at the metropolitan region of Rio de Janeiro (RJ, Brazil). Cien. Saude Colet. 2010; 15(Suppl 3): 3579-86.

23. Protasio AL, Silva PB, Lima EC, Machado LS, Valença AG, Gomes LB. Assessment of the referral and counter-referral system in the state of Paraíba according to Primary Care professionals in the context of the 1st cycle of external assessment of the PMAQ-AB. Saúde Debate. 2014; 38(n. especial): 209-20.

CORRESPONDING

AUTHOR

EMMANUELLY CORREIA DE LEMOS

emmanuellylemos@gmail.com
Rua Falcão, nº 22, Ouro Preto, Olinda,

Pernambuco. CEP: 53370-101.

Telephone: +55 (81) 997190294
RECEIVED

$02 / 12 / 2015$

$25 / 02 / 2016$

$31 / 03 / 2016$

$26 / 04 / 2016$

APPROVED 29/04/2016 